\author{
dr Magdalena Białek \\ Uniwersytet Wrocławski \\ Instytut Filologii Germańskiej \\ tel. 713752452 \\ e-mail: magdalena.bialek@uwr.edu.pl
}

\title{
POTENCJAL KOMUNIKACYJNY PODRĘCZNIKÓW DO NAUKI JĘZYKA OBCEGO NA PRZYKŁADZIE JĘZYKA NIEMIECKIEGO
}

\begin{abstract}
STRESZCZENIE
Od ponad 40 lat obowiq̨zującym podejściem w kształceniu obcojęzycznym jest podejście komunikacyjne, a najważniejszym celem edukacji językowej jest rozwijanie kompetencji komunikacyjnej. Jednak jak pokazuje historia, ani realizacja podejścia komunikacyjnego, ani osiąganie kompetencji komunikacyjnej przez uczących się nie są łałwymi celami w procesie formalnej nauki języka obcego. Kształcenie językowe warunkowane jest bowiem przez wiele czynników, a za jeden z nich uznać można niewątpliwie podręcznik. W niniejszym artykule przedstawia się wyniki analizy podręcznika do nauki języka niemieckiego pod kątem jego potencjału komunikacyjnego. W tym celu odwołuje się do zasad komunikacji międzyludzkiej w ogóle, teoretycznych rozważań obecnych w literaturze przedmiotu, a także dostępnych praktycznych rozwiązań dydaktycznych. Jak pokazuje badanie, podręczniki (w artykule zaprezentowany jest jeden, całe badanie objęło analizę kilku) odznaczają się niskim potencjałem komunikacyjnym. Świadczą o tym m.in. niewielka liczba tekstów autentycznych, niewłaściwie formułowanie poleceń czy też brak zadań komunikacyjnych. Za interesujące i właściwe dla grupy docelowej można byłoby uznać tematy leksykalne pojawiające się w analizowanych podręcznikach, lecz ich realizacja (wyrażająca się w koncepcji ćwiczeń) odbiega od komunikacyjnego schematu obowiq̨zującego współcześnie podejścia. I choć wiadomo, że podręcznik to tylko jedna z możliwych pomocy dydaktycznych, to z drugiej strony wiadomo również, ze większość nauczycieli bardzo chętnie z niego korzysta i wiernie odtwarza tok lekcji według instrukcji podręcznikowych. W kontekście tak dużego „przywiązania" nauczycieli do podręczników, powinno się w sposób szczególny monitorować ich jakość i dq̨żyć do jak najbardziej optymalnych rozwiq̨zań przy ich tworzeniu.
\end{abstract}

Słowa kluczowe: podejście komunikacyjne, kompetencja komunikacyjna, zadania komunikacyjne 


\section{SUMMARY \\ Communication potential of textbooks for learning a foreign language on the example of German language}

For more than 40 years, the current approach in foreign language education has been the communication approach, and the most important goal of language education is to develop communication skills. But as history shows, neither the communication approach nor the communicative competence of learners are easy targets for the formal learning of a foreign language. Language training is conditioned by many factors, and one of them is undoubtedly the textbook. This article presents the results of the analysis of German language textbook in terms of its communication potential. To this end, it refers to the principles of interpersonal communication in general, the theoretical considerations present in the literature of the subject, as well as the available practical teaching solutions. As the survey shows, textbooks have low communication potential. This is evidenced by, among others, a small number of authentic texts, improperly formulated instructions, or lack of communication tasks. It would be interesting and appropriate from the perspective of the target group to recognize the lexical themes appearing in the analyzed textbooks, but their implementation (expressed in the concept of exercise) differs from the communicative schema of today's approach. Although it is known that the textbook is only one of the possible teaching aids, on the other hand it is also known that most teachers are eager to use it and faithfully reproduces the course of the lesson according to the instruction manual. In the context of so much "attachment" of teachers to textbooks, one should monitor their quality in detail and strive for optimal solutions for their development.

Key words: communication approach, communicative competence, communication tasks

\section{Wstęp}

Podejście komunikacyjne, w ramach którego ponad 40 lat temu zaczęto na lekcjach języka obcego promować formy interakcji jak najbardziej zbliżone do autentycznej komunikacji, usankcjonowało w sposób formalny i naukowy, prymarny i oczywisty zarazem cel kształcenia obcojęzycznego, jakim jest kompetencja komunikacyjna. Od tamtego czasu samo podejście komunikacyjne, jak i kompetencja komunikacyjna stały się przedmiotem rozważań teoretycznych i badań empirycznych. Trudno wskazać osobę spośród grona glottodydaktyków, która w swoich pracach w sposób mniej lub bardziej bezpośredni nie nawiązywałaby do wspomnianych wyżej pojęć. W ten sposób podejście komunikacyjne stało się swoistym leitmotivem, który - w zależności od potrzeb, a może też mody - pojawiał się częściej lub rzadziej w literaturze przedmiotu. Wydaje się, że jedną z istotniejszych kwestii jest tutaj ten kierunek badań, w którym próbuje się ustalić, z jaką skutecznością podejście komunikacyjne przyczynia się 
do rozwijania kompetencji komunikacyjnej. Z jednej strony, odpowiedź można byłoby uznać za oczywistą, stwierdzając, że kompetencja ta jest naturalną konsekwencją stosowania podejścia komunikacyjnego. Tymczasem, jak pokazuje historia, w praktyce nie zawsze da się zauważyć tę - wydawać by się mogło naturalną - współzależność. Żeby jej dowieść (bądź ją zanegować), szczegółowym badaniom poddaje się takie subdyscypliny glottodydaktyki jak: pedeutologia, akwizycja języków obcych, lingwistyka dydaktyczna, preparacja i ewaluacja materiałów glottodydaktycznych, glottometodyka oraz mediadydaktyka ${ }^{1}$. W niniejszym artykule uwaga skupiona zostanie na komunikacyjnym potencjale podręczników do języka obcego. Jak wynika z badań (np. zakrojonych na szeroką skalę badań uwieńczonych „Raportem o stanie edukacji 2013”2), dla 98\% nauczycieli języków obcych podręcznik jest najważniejszą pomocą dydaktyczną, a dołączone do niego materiały dźwiękowe wykorzystywane są przez $92 \%$ pedagogów. Dla przeciwwagi można przytoczyć odpowiedzi z tego samego badania, wskazujące na mały odsetek procentowy (1\%) nauczycieli wykorzystujących $\mathrm{w}$ procesie dydaktycznym materiały autentyczne, takie jak gazety, czasopisma, komiksy, czy teksty obcojęzycznych piosenek. Również $1 \%$ badanych stosuje w kształceniu językowym książki obcojęzyczne w celu pogłębienia sprawności czytania. Te dane przedstawiają dość pesymistyczny obraz polskiej rzeczywistości, szczególnie w kontekście rozumienia materiałów autentycznych jako jednego z najlepszych źródeł danych wejściowych językowych, czyli tzw. dobrego inputu (por. teoria Krashena) ${ }^{3}$. Nietrudno byłoby w tej sytuacji skierować krytykę w stronę nauczycieli języka obcego, którzy - opierając się przede wszystkim na podręczniku - nie włączają w proces dydaktyczny innych materiałów (jak wynika z przywołanych wyżej badań). Taka krytyka byłaby jednak dość tendencyjną reakcją, świadczącą o braku szerszej refleksji i całościowego spojrzenia na problematykę kształcenia językowego w polskich realiach. Szerszy kontekst interpretacyjny tego zagadnienia nie uprawomocnia do szukania winnych wyłącznie w środowisku nauczycielskim. Status quo polskiej edukacji obcojęzycznej jest przecież wypadkową wielu czynników, spośród których nauczyciel jest tylko jednym z elementów układu glottodydaktycznego. Innymi istotnymi czynnikami są tutaj: uczeń, język, materiały glottodydaktyczne, metoda nauczania i uczenia się, środowisko szkolne, obiektywna rzeczywistość, środowisko społeczne i polityka edukacyjna państwa. Te elementy

\footnotetext{
1 Subdyscypliny podano za: W. Pfeiffer, Nauka języków obcych. Od praktyki do praktyki, Poznań 2001.

2 Raport o stanie edukacji 2013. Licza się nauczyciele, http://eduentuzjasci.pl/publikacje-ee-lista/raporty /150-raport-o-stanie-edukacji/1052-raport-o-stanie-edukacji-2013-licza-sie-nauczyciele.html, [online], dostęp 1.07.2017.

3 S.D. Krashen, The Input Hypothesis: Issues and Implications, New York 1985.
} 
konstytuujące układ glottodydaktyczny według Pfeiffera ${ }^{4}$ pokazują, w jak szerokiej skali należy rozpatrywać wszelkie zagadnienia edukacji obcojęzycznej. Rozumiejąc w taki właśnie sposób kontekst kształcenia obcojęzycznego w warunkach formalnych, podejmuje się $\mathrm{w}$ niniejszym artykule próbę odpowiedzi na pytanie, na ile podstawowe medium w pracy nauczyciela języka obcego, jakim jest podręcznik, pozwala na realizowanie zasady komunikatywności, czyli inaczej mówiąc, $\mathrm{w}$ jakim stopniu ćwiczenia i zadania zawarte $\mathrm{w}$ podręcznikach mają potencjał komunikacyjny, na ile przy ich umiejętnym wykorzystaniu można upodobnić proces uczenia się języka obcego do procesów rzeczywistej komunikacji. Upodobnienie do rzeczywistej komunikacji nie oznacza tutaj chęci niepotrzebnego, wręcz szkodliwego „udawania”, że sytuacja jest inna niż rzeczywiście jest. Sytuacja formalnej nauki języków obcych ma swoje ograniczenia, a ignorowanie ich mogłoby prowadzić do "pułapki realnego życia" i podejmowania stałych prób zmiany czegoś, czego zmienić nie można i zmieniać nie należy. Odnosząc się do wspomnianego wyżej szerokiego kontekstu interpretacyjnego edukacji podkreślić należy, że niniejsze badanie ogranicza się tylko do analizy podręcznika (jako jednego $\mathrm{z}$ wielu możliwych elementów mogących wpłynąć na komunikacyjny charakter lekcji), w związku z czym na jego podstawie nie można sformułować wniosków na temat kondycji lekcji języka obcego w ogóle. Inną ciekawą sprawą w tym kontekście jest jeszcze sposób realizacji treści podręcznikowych przez nauczycieli, lecz ta kwestia również nie jest przedmiotem rozważań niniejszego artykułu. Jego celem jest natomiast zaprezentowanie, jaki potencjał komunikacyjny znajdują nauczyciele języka niemieckiego w najczęściej wykorzystywanej przez nich pomocy dydaktycznej. Prezentację wyników badania poprzedza się teoretycznym uszczegółowieniem tematu, będącym punktem odniesienia w badaniach empirycznych.

\section{Komunikacja na lekcji języka obcego}

W 2006 roku Parlament Europejski określił kompetencje kluczowe w procesie uczenia się przez całe życie ${ }^{6}$. Przywołanie tego często cytowanego dokumentu znajduje swoje uzasadnienie również i tutaj, ponieważ na osiem kompetencji kluczowych uznanych za najważniejsze w perspektywie całego życia

\footnotetext{
4 W. Pfeiffer, op. cit.

5 M.A. Swan, A critical look at the Communicative Approach, http://seas3.elte.hu/co-ursematerial/Hala piMagdolna/Swan1.pdf, [online], dostęp 15.08.2017.

6 Kompetencje kluczowe w procesie uczenia się przez całe życie, http://eur-lex.europa.eu/legal-content/ PL/TXT/?uri=LEGISSUM\%3Ac11090, [online], dostęp 15.08.2017.
} 
„porozumiewanie się w języku obcym” jako kompetencja kluczowa pojawia się na drugim miejscu, zaraz po niekwestionowanym numerze jeden, czyli komunikowaniu się $\mathrm{w}$ języku ojczystym. Autorzy dokumentu podkreślają, że porozumiewanie się $w$ obcych językach opiera się $w$ znacznej mierze na tych samych umiejętnościach co porozumiewanie się w języku ojczystym - na zdolności do rozumienia, wyrażania i interpretowania pojęć, myśli, uczuć, faktów i opinii w mowie i piśmie (rozumienie ze słuchu, mówienie, czytanie i pisanie) w odpowiednim zakresie kontekstów społecznych i kulturalnych (w edukacji, pracy, domu i czasie wolnym) w zależności od chęci lub potrzeb danej osoby. Aby móc się komunikować, potrzebna jest znajomość słownictwa oraz gramatyki funkcjonalnej, a także świadomość głównych typów interakcji słownej i rejestrów języka. Duże znaczenie przypisuje się również aspektowi kulturowemu, tj. rozwijaniu świadomości różnorodności kulturowej oraz postawie ciekawości języków i komunikacji międzykulturowej ${ }^{7}$. W świetle tego dokumentu dydaktyka obcojęzyczna staje przed bardzo odpowiedzialnym zadaniem, jakim jest przygotowanie uczących się do komunikacji w międzynarodowym wymiarze.

W kontekście stricte polskim i typowo glottodydaktycznym wagę i znaczenie komunikatywności w kształceniu obcojęzycznym podkreśla m.in. Lewicki ${ }^{8}$, uznając ją za prymarną zasadę dydaktyczną. Uszczególawiając definicję komunikatywności, wyróżnia on w jej obrębie kompetencję interakcyjną, językową i socjokulturową. Wydaje się zatem, że założenia Lewickiego z 2002 roku znalazły swoje odzwierciedlenie w dokumencie Parlamentu Europejskiego. Zarówno w jednym, jak i w drugim przypadku podkreśla się konieczność umiejętności wyboru i zastosowania odpowiednich do danej sytuacji językowej schematów wypowiedzi i środków wyrazu, co związane jest z gotowością do językowego ryzyka i tolerancji błędu. Za niezbędną uznawana jest wiedza językowa umożliwiająca budowanie poprawnych wypowiedzi. Tym, czego nie można pominąć we współczesnym obrazie socjokulturowym, jest świadomość konieczności nauczania o szeroko rozumianej kulturze.

Bardzo potrzebne rozważania teoretyczne wymagają jeszcze propozycji aplikacji, szczególnie wtedy, kiedy dotyczą konkretnych sytuacji lekcyjnych, które $\mathrm{z}$ definicji przecież zorientowane są na praktykę. Takie aplikatywne uszczegółowienie tematu znaleźć można w publikacji Komorowskiej9. Sukces ćwiczeń i zadań zaproponowanych przez autorkę polega na uwzględnieniu w nich poszczególnych zasad komunikacji językowej, co daje szansę ukomunikatywnienia sytuacji lekcyjnej. Osiąga się to poprzez umiejętne formułowanie

\footnotetext{
7 Ibidem.

8 R. Lewicki, Poznaj język sąsiada. Program nauczania. Język niemiecki, Warszawa 2002.

9 H. Komorowska, Ćwiczenia komunikacyjne w nauce języka obcego, Warszawa 1988.
} 
poleceń do zadań, które - spełniając swoją kierowniczą i stymulującą funkcję - nadają aktywnościom lekcyjnym wymiar komunikacyjny, a przez to zapewniają uczniom możliwość m.in. tzw. sensownego działania. W konsekwencji uczący się nie muszą działać w przekonaniu, że wykonują zadanie dla samego zadania, lecz mają szansę uznać je za warte wykonania ze względu na ich pragmatyczny cel. Język docelowy staje się $\mathrm{w}$ takiej sytuacji narzędziem. W swoich zadaniach Komorowska ${ }^{10}$ odwołuje się m.in. do następujących zasad komunikacji językowej:

- niskiej prognostyczności aktu komunikacji językowej,

- zjawiska redundancji,

- zjawiska luki informacyjnej,

- tzw. reguł użycia języka,

- elementów niewerbalnych,

- zjawiska łącznego występowania sprawności.

Niska prognostyczność wypowiedzi w akcie komunikacji jest podstawową cechą każdej komunikacji. Nieprzewidywalność zachowań komunikacyjnych człowieka oraz niepowtarzalność każdej sytuacji powodują, że uczeń zostanie w przyszłości skonfrontowany z innymi pytaniami i wypowiedziami niż te ćwiczone w czasie lekcji w odniesieniu do stereotypowych sytuacji. Dlatego też, jak zaleca Komorowska, wskazane jest $\mathrm{w}$ trakcie nauki m.in. położenie nacisku na sprawności receptywne - po to, by uczeń był w stanie zrozumieć jak najwięcej różnych komunikatów (możliwych w tej samej sytuacji). Można to osiągnąć poprzez odpowiednio intensywny kontakt z różnego rodzaju tekstami obcojęzycznymi oraz ćwiczeniami $\mathrm{w}$ rozumieniu ze słuchu. W zakresie sprawności produktywnych zaleca się ćwiczenia polegające na wyrażaniu tej samej intencji za pomocą zróżnicowanych środków językowych, różnicowanie kręgu odbiorców, posługiwanie się techniką parafrazy czy też wcielanie się w różne role celem relacjonowania z pozycji różnych osób ${ }^{11}$.

Nadwyżka środków językowych w określonym akcie komunikacji pozwala na rozumienie komunikatów w pewnym stopniu uszkodzonych, skondensowanych czy też wypowiadanych $\mathrm{w}$ warunkach hałasu lub zgiełku ${ }^{12}$. Wykorzystanie zjawiska redundancji na lekcji możliwe jest poprzez konfrontowanie uczniów z tekstami niepełnymi, zróżnicowanymi, w pewien sposób uszkodzonymi lub skrótowymi. Ważne w tym kontekście jest również prezentowanie tekstów wraz z czynnikami zagłuszającymi, co można osiągnąć m.in. poprzez równoległą pracę $\mathrm{w}$ grupach, która w sposób oczywisty generuje pewien poziom hałasu.

\footnotetext{
10 Ibidem.

11 Ibidem, s. 37.

12 Ibidem, s. 45.
} 
Wykorzystanie kolejnej (proponowanej przez Komorowską) cechy komunikacji w dydaktyce języków obcych, czyli zjawiska luki informacyjnej, wydaje się być czymś naturalnym, gdyż z reguły komunikujemy się celem zniwelowania określonej luki w naszej wiedzy. Na lekcji języka obcego można wprowadzić „lukę informacyjną", stosując ćwiczenia, w których tak różnicuje się poziom wiedzy uczniów, aby zadawane pytania wynikały rzeczywiście z braku wiedzy lub z autentycznej ciekawości (o taką sytuację znacznie trudniej). W innym wypadku, kiedy odpowiedź jest znana uczniowi zadającemu pytanie lub też znajduje się ona bezpośrednio w zasięgu jego wzroku, wszelkie próby interakcji obcojęzycznej będzie można nazwać pseudokomunikacją. Pseudokomunikację wzmacniać będą na przykład dość popularne pytania "oczywiste" (kierowane przez nauczyciela do uczniów, mimo że odpowiedź jest mu dobrze znana), a osłabić ją mogą wszelkiego typu zagadki, zabawy w zadawanie pytań czy też praca techniką stolików eksperckich.

Ćwiczenia uwzględniające reguły użycia języka, kolejne z listy Komorowskiej, wydają się być szczególnie ważne w odniesieniu do podręcznika i jego potencjału komunikacyjnego. Podręcznik uwzględniający reguły użycia języka to taki, który zawiera dużą liczbę zróżnicowanych tekstów, prezentujących różne warianty stylistyczne czy też różnorodne realizacje intencji komunikacyjnych. Przez tak rozumianą różnorodność podręcznik dostarcza uczącym się bogatego doświadczenia receptywnego, które stanowi podstawę do wytworzenia i zorganizowania mentalnej reprezentacji systemu językowego oraz programów sterujących produkcją językową. Teksty zdydaktyzowane, formułowane w oparciu o progresję gramatyczną i leksykalną nie mają siły inicjującej, tzn. rzadko uruchamiają wewnętrzne procesy rozumienia, bo są mało ważne, mało ciekawe i interesujące ${ }^{13}$.

Kodowane przez nadawcę i odkodowywane przez odbiorcę sygnały społeczne to komunikaty niewerbalne, których uwzględnienie w komunikacji lekcyjnej proponuje również Komorowska. Ćwiczenia uwzględniające niewerbalne elementy komunikacji obejmują interpretację gestów, tłumaczenie komunikatorów niewerbalnych na werbalne, a także powszechnie znaną pantomimę oraz symulację bez użycia słów.

W perspektywie przygotowania do autentycznej komunikacji umiejętność łączenia sprawności językowych w jednym akcie komunikacji wydaje się być kluczowa, ponieważ współwystępowanie i współistnienie różnych sprawności językowych jest cechą charakterystyczną komunikacji. Odpowiednio dobrane ćwiczenia pozwalają na rozwijanie tej umiejętności w formalnym kształceniu językowym.

13 J. Iluk, Jak (de)motyzujemy uczniów na lekcjach języka obcego, „Języki Obce w Szkole” 2013, 4, s. 67-74. 


\section{Opis badania}

Przedstawione $w$ niniejszym artykule badanie jest fragmentem zakrojonego na szerszą skalę projektu badawczego, polegającego na analizie podręczników do języka niemieckiego pod kątem występowania w nich aktywności zapewniających uczącym się tzw. sensowne działanie poprzez zastosowanie zadań komunikacyjnych. W badaniu właściwym analizie poddaje się kilkanaście podręczników przeznaczonych dla różnych grup wiekowych. W niniejszym artykule przedstawione zostały wyniki analizy jednego podręcznika do nauki języka niemieckiego pod kątem (jak wspomniano wyżej) jego potencjału komunikacyjnego. Celem uzyskania jak najbardziej dokładnych i rzetelnych wyników zdecydowano się na zastosowanie linearnej analizy jednego podręcznika, polegającej na szczegółowym opisie kolejnych ćwiczeń i zadań w nim występujących. Jak wynika z analizy dokumentacji praktyk studenckich, analizowany podręcznik był najpopularniejszym podręcznikiem używanym w szkołach na Dolnym Śląsku w roku szkolnym 2016/2017. Przeznaczony jest on dla trzeciej klasy gimnazjum, realizującej obowiązek nauki drugiego języka obcego w wymiarze dwóch godzin tygodniowo. Poddana analizie część podręcznika to ostatni tom z sześciotomowej serii, czyli podręcznik z podtytułem $3 b$, wykorzystywany $\mathrm{w}$ ostatnim semestrze ostatniego roku nauki w szkole gimnazjalnej.

Potencjał komunikacyjny podręcznika przeanalizowany został $\mathrm{w}$ odniesieniu do wspomnianych w części teoretycznej wytycznych, a jednocześnie, dla większego porządku, w odniesieniu do poszczególnych, powszechnie przejętych procedur lekcji. Tak więc ostatecznie przeanalizowano, na ile i w jaki sposób można ukomunikatywnić sytuację lekcyjną w każdej z jej procedur, tj. sensybilizacji, wprowadzeniu, semantyzacji (ze względu na mały potencjał komunikacyjny ta procedura nie zostanie poddana szczegółowemu opisowi w dalszej części badania), utrwaleniu $\mathrm{w}$ toku ćwiczeń wdrażających, utrwaleniu $\mathrm{w}$ toku ćwiczeń sprawnościowych, zastosowaniu, czyli swobodnej praktyce językowej ${ }^{14}$. Oprócz wspomnianych wyżej wytycznych przy określaniu potencjału komunikacyjnego podręcznika odwołano się również do spisu zadań komunikacyjnych autorstwa Willis (2007) ${ }^{15}$ :

14 Procedury podano za: R. Lewicki, op. cit.

15 D. Willis, Accuracy, fluency and autonomous learning: A three way distinction, http://www.williselt.co. uk/books.html, [online], dostęp 15.08.2017. 
Tabela 1. Rodzaje zadań komunikacyjnych według Willis ${ }^{16}$

\begin{tabular}{|l|l|}
\hline \multicolumn{1}{|c|}{ Typ zadania } & \multicolumn{1}{c|}{ Przykłady } \\
\hline Tworzenie list & $\begin{array}{l}\text { burza mózgów lub poszukiwanie faktów dotyczących } \\
\text { rzeczy, osób, miejsc, przyczyn lub cech charakterystycznych }\end{array}$ \\
\hline $\begin{array}{l}\text { Sortowanie } \\
\text { i układanie } \\
\text { w kolejności }\end{array}$ & $\begin{array}{l}\text { tworzenie rankingów, klasyfikowanie, tworzenie sekwencji, } \\
\text { np. obrazków podczas opowiadania, historyjki }\end{array}$ \\
\hline Łączenie & $\begin{array}{l}\text { słuchanie i identyfikowanie, słuchanie i wykonywanie } \\
\text { polecen, łączenie fraz, opisów i obrazków, łączenie } \\
\text { wskazówek i map }\end{array}$ \\
\hline Porównywanie & $\begin{array}{l}\text { poszukiwanie podobieństw i różnic, na przykład } \\
\text { przez porównywanie dwóch podobnych obrazków lub } \\
\text { kontrastowanie dwóch pór roku }\end{array}$ \\
\hline $\begin{array}{l}\text { Rozwiązywanie } \\
\text { problemów }\end{array}$ & $\begin{array}{l}\text { łamigłówki logiczne, analizy przypadków, autentyczne } \\
\text { życiowe problemy, przewidywanie zakończenia opowieści } \\
\text { lub proponowanie własnych rozwiązań }\end{array}$ \\
\hline $\begin{array}{l}\text { Projekty i zadania } \\
\text { kreatywne }\end{array}$ & $\begin{array}{l}\text { opracowywanie i przeprowadzanie ankiet, tworzenie } \\
\text { gazetki klasowej lub planowanie programu radiowego }\end{array}$ \\
\hline $\begin{array}{l}\text { Dzielenie się } \\
\text { osobistymi } \\
\text { doświadczeniami }\end{array}$ & $\begin{array}{l}\text { opowiadanie historyjek, anegdot i wspomnień, wyrażanie } \\
\text { opinii lub własnych reakcji }\end{array}$ \\
\hline
\end{tabular}

\subsection{Potencjał komunikacyjny sensyblilizacji zwanej rozgrzewką językową}

Według Lewickiej ${ }^{17}$ sensybilizacja polega na ogólnym wprowadzeniu uczących się w planowany kontekst działania i jednoczesnym przygotowaniu bazy do prawidłowej semantyzacji. Przez odpowiednie działania językowe i pozajęzykowe następuje aktywizacja dotychczasowej wiedzy, doświadczeń i umiejętności. Można zatem powiedzieć, że sensybilizacja na lekcji języka obcego, zwana również popularnie rozgrzewką językową, pełni dwie podstawowe funkcje: motywującą oraz autonomizującą. Motywująca funkcja rozgrzewki, polegająca na zainteresowaniu ucznia tematem oraz wprowadzeniu go w stan gotowości do dalszego działania, wydaje się mieć tutaj zasadnicze znaczenie, albo-

16 Ibidem.

17 G. Lewicka, Glottodydaktyczne aspekty akwizycji języka drugiego a konstruktywistyczna teoria uczenia się, Wrocław 2007. 
wiem może ona przesądzić o postawie uczącego się, jego nastawieniu i chęci do dalszego zaangażowanego uczestnictwa w lekcji. Natomiast autonomizująca funkcja rozgrzewki rozumiana jest jako rozwijanie konkretnych, indywidualnych strategii przygotowujących do samoregulacyjnych działań w opanowywania języka. Niezaprzeczalnym atutem sensybilizacji jest również utrwalanie $w$ jej ramach nawyku swobodnego wypowiadania się.

W badanym podręczniku na 15 przeanalizowanych tematów sensybilizacja sensu stricto występuje trzy razy. Po raz pierwszy, kiedy uczniowie mają okazję uzupełnić asocjogram do tematu „mieszkać, żyć”, co można porównać $\mathrm{z}$ tworzeniem list u Willis (2007). Przez odpowiednie działania językowe i pozajęzykowe następuje aktywizacja dotychczasowej wiedzy, doświadczeń i umiejętności. Przez łączenie datum z novum uczący się przygotowani są na przyjęcie nowych treści i ich interpretację ${ }^{18}$. Drugi przykład spełniający kryteria sensybilizacji polega na opisywaniu obrazków, antycypowaniu dalszych zdarzeń oraz przewidywaniu losów rysunkowych postaci. Trzecia możliwość uwrażliwienia uczniów na zaplanowane treści lekcji to zachęcanie do dzielenia się osobistym doświadczeniem (tu: preferencje uczniów odnośnie do szkoły). Pomocą są obrazki i środki leksykalne, które mogą być wykorzystane w swobodnej wypowiedzi. Tylko te trzy przykłady mogą zostać uznane za właściwy i motywujący sposób rozpoczęcia lekcji. Pozostałe jednostki lekcyjne w podręczniku rozpoczynają się globalnym rozumieniem tekstu (2 razy), dopasowywaniem usłyszanych bądź przeczytanych haseł do obrazków (7 razy), opisem obrazka (bez pytań antycypujących, chyba że nauczyciel zdecyduje inaczej - 1 raz). Taka koncepcja podręcznika nie przesądza jednak $\mathrm{w}$ żaden sposób o ostatecznym kształcie lekcji, o którym przecież decyduje nauczyciel. O tym jednak, że podręczniki stwarzają niejako pokusę ślepego i bezrefleksyjnego podążania za ich treściami i sposobem ich realizacji, pisze Allwright $(1981)^{19}$ stwierdzając, że współczesne podręczniki pisane są z zamiarem stworzenia wrażenia „absolutnej doskonałości”. Zakłada się, że podręcznik jest tak dobry, że może być wykorzystywany nawet przez nauczycieli o niskich kwalifikacjach metodycznych. Efektem ma być stworzenie fałszywego poczucia bezpieczeństwa i komfortu, wynikającego z przekonania, że podręczniki pisane są przez profesjonalnych metodyków i nauczyciel jest właściwie niepotrzebny. Jedyną rzeczą, którą nauczyciel powinien zrobić, jest włączenie systemu i spowodowanie, że proces nauczania przebiega bezproblemowo. W literaturze anglojęzycznej takie materiały noszą nazwę „odpornych na nauczy-

18 G. Lewicka, op. cit., s. 116.

19 R. L. Allwright, What do we want teaching materials for?, „ELT Journal 36” 1981, 1, s. 5-18. 
ciela" (ang. teacher-proof materials) ${ }^{20}$. Jak podkreśla Swan ${ }^{21}$, takie spojrzenie na podręcznik może spowodować, że nauczyciel czuje się zwolniony z odpowiedzialności za proces nauczania, który prowadzi. Zamiast traktować podręcznik jako jeden $\mathrm{z}$ dostępnych poradników, pomocnych $\mathrm{w}$ swoich działaniach, korzysta z podręcznika bezkrytycznie, bez świadomości zasad metodycznych, którymi kierowali się autorzy podręcznika, nie rozumiejąc jego braków i niedoskonałości.

\subsection{Wprowadzenie - potencjał komunikacyjny tekstów i tematów}

Jak wspomniano w części teoretycznej artykułu, duże znaczenie w przygotowaniu do autentycznej komunikacji ma kształcenie sprawności receptywnych, możliwe do osiągnięcia przede wszystkim przez zastosowanie zasad tzw. dobrego inputu. Oprócz tej funkcji równie ważny wydaje się być potencjał motywacyjny tekstów, o którym można mówić w przypadku pokrywania się występujących $\mathrm{w}$ nim treści $\mathrm{z}$ preferencjami uczniów i ich zainteresowaniami. Jest to szczególnie ważne wobec faktu, iż większość podręczników (w tym również poddany analizie $\mathrm{w}$ opisywanym badaniu) realizuje linearną progresję tematyczną, zgodnie $\mathrm{z}$ którą $\mathrm{w}$ czasie jednego semestru realizowane są cztery tematy, co oznacza, że jeden temat omawiany jest średnio przez miesiąc ${ }^{22}$. Biorąc pod uwagę ten relatywnie długi czas przeznaczony na realizację jednego tematu, poruszane zagadnienia powinny być dostosowane do profilu zainteresowań uczących się ${ }^{23}$. W analizowanym podręczniku cztery tematy przewidziane na ostatni semestr nauki to: kultura, barwy mojego świata, dzisiaj i jutro oraz duży quiz wiedzy.

Pierwszy temat - kultura - może brzmieć dla nastolatków zachęcająco. Wydaje się jednak, że realizacja tej jednostki leksykalnej w opisywanym podręczniku (wybór tematów szczegółowych oraz tekstów towarzyszących) może

20 M. Kusiak-Pisowacka, Ewaluacja podręcznika w nauczaniu języków obcych, Lingwistyka Stosowana 2015, 14: 3, s. 65-75.

21 M. Swan, The textbook: bridge or wall?, Applied Linguistics and Language Teaching 1992, 2/1, s. 32-35.

22 Por. J. Iluk, op. cit.

23 Niełatwo oczywiście stworzyć taki profil i wybrać cztery wiodące tematy na pół roku nauki. W tym trudnym zadaniu pomagają niewątpliwie badania empiryczne, np. Iluk (op. cit.) w swojej publikacji przedstawia listę tematów interesujących młodzież, dodatkowo z podziałem na płeć. Okazuje się, że najbardziej popularne zagadnienia wśród dziewcząt to hobby i spędzanie wolnego czasu, stosunki międzyludzkie, komputer i technika, filmy oraz miłość. Natomiast wśród pięciu najbardziej popularnych tematów wskazanych przez chłopców znalazły się filmy, komputer i technika, sport, hobby i spędzanie wolnego czasu oraz miłość. 
trochę rozczarowywać. W ramach "kultury” proponuje się uczniom rozmowę przede wszystkim na temat tzw. kultury wysokiej. Pojawia się jeden tekst zdydaktyzowany, informujący o inicjatywnie młodzieży niemieckiej polegającej na wydawaniu broszury na temat wydarzeń kulturalnych w ich mieście (nie pojawia się przykład samej broszury - co potencjalnie mogłoby interesować). Drugi tekst to raczej autentyczna wzmianka na temat oferty kinowej, teatralnej i koncertowej w Hamburgu (wymienione zostały po trzy tytuły dla trzech wymienionych wyżej instytucji oraz podane zostały ich adresy). Być może takie zestawienie informacji mogłoby wzbudzić zainteresowanie uczących się, wynikające $\mathrm{z}$ możliwości porównania paralelnych wydarzeń niemieckich i polskich. Istnieje jednak obawa, że porównania takie nie mają $w$ tej sytuacji sensu ze względu na coroczne przecież dezaktualizowanie się informacji w podręczniku. Drugi temat w omawianej jednostce leksykalnej brzmi "Czytanie jest trendy". Wydaje się, że potencjał komunikacyjny i motywacyjny tego zagadnienia jest względnie duży. Warunkiem byłoby tu jednak kontrowersyjne podejście do tematu ze względu na wiadomy stosunek współczesnej młodzieży do czytania. Biorąc pod uwagę, że w przypadku opisywanego podręcznika grupą docelową są trzecioklasiści, umożliwienie im wyrażenia opinii, przekonań i własnych argumentów na powyższy temat można uznać za warunek sensownego i komunikacyjnego działania w kontekście omawianego tematu. Analiza podręcznika pokazuje jednak, że obiera się w nim inny kierunek realizacji tematu. Pojawiają się teksty encyklopedyczne, definiujące różne gatunki literackie oraz fragment ze strony internetowej amazon.de, ukazujący klasyfikację literatury ze względu na rodzaje literackie. Trudno nie stwierdzić, że temat został w podręczniku przedstawiony tendencyjnie, bez kreatywnej koncepcji, w mało interesujący sposób. Sytuacja wygląda bardzo podobnie w przypadku realizacji kolejnego tematu tj. „Jeśli muzyka sprawia wam przyjemność, to...". Muzyka to temat $\mathrm{z}$ toplisty młodych ludzi. Niestety, potencjał komunikacyjny tej jednostki tematycznej kończy się na trafionym wyborze tematu. Realizacja tematu ogranicza się do pracy z krótkimi, nieautentycznymi dialogami, odbywającymi się na koncercie, w dyskotece, w operze itd. Sam podręcznik nie stwarza możliwości do wyrażenia osobistej opinii na temat muzyki, przeprowadzenia dyskusji bądź debaty na ten - zawsze, a szczególnie dla młodzieży - aktualny temat.

Drugi rozdział „Kolory mojego świata” zawiera kilka tekstów autentycznych, tj. obszerną ofertę domu wczasowego, trzy krótsze propozycje spędzenia wakacji (oferty biur turystycznych) oraz przepis na spaghetti (podobny do tych, które można znaleźć na stronach internetowych) oraz taką samą liczbę tekstów zdydaktyzowanych. W ramach tej jednostki leksykalnej przez ok. cztery tygodnie uczniowie pracują nad następującymi tematami: cechy charakteru, 
oferty wakacyjne oraz zdrowe odżywianie. Trudno stwierdzić, czy są to tematy interesujące dla młodzieży. Prawdopodobnie dla części tak, a dla części nie. Być może teksty autentyczne, przedstawiające oferty spędzenia wakacji mogą zainteresować uczących się ze względu na swój potencjał informacyjny. Zamieszczona w podręczniku piramida żywienia też mogłaby stać się inspiracją do dyskusji. Podobnie cechy charakteru przypisane poszczególnym znakom zodiaku mogą być potencjalnie interesujące dla opisywanej grupy docelowej. Wydaje się, że w przypadku zagadnienia leksykalnego, jakim są "kolory mojego świata", wiele będzie zależało od nauczyciela. Sam temat, odnoszący się przecież do życia i rzeczywistości uczących się, ma już chociażby $\mathrm{z}$ tego powodu pewien potencjał motywacyjny. Wiele będzie zależało od jego realizacji.

Trzeci temat w obrębie jednostki leksykalnej - „kultura” to „dziś i jutro”. Porusza się tutaj temat rodziny, szkoły i wymarzonych zawodów. Oprócz tradycyjnych, zdydaktyzowanych tekstów pojawia się jeden tekst autentyczny, tj. fragment forum internetowego, którego realny charakter manifestuje się $\mathrm{w}$ niepełnych zdaniach (zdanie bez podmiotu), skrótach, niedokończonych zdaniach, błędach ortograficznych (rzeczownik - nazwa własna małą literą). Takie zabiegi stanowią bezsprzeczną próbę ukomunikatywnienia sytuacji lekcyjnej. Teksty zdydaktyzowane wydają się być bardzo tendencyjne, "suche", wręcz encyklopedyczne, w pewien sposób stereotypowe i oderwane od rzeczywistości. Dla przykładu przytoczyć można fikcyjną wypowiedź gimnazjalistki, która chce zostać modelką i jej kolegi, którego wymarzonym zawodem jest murarz, mimo, że pracuje on $\mathrm{w}$,złych i ciężkich warunkach, na przykład jesienią, kiedy pada deszcz i wieje silny wiatr". Taka narracja nie przypomina raczej rozmów gimnazjalistów na temat ich przyszłości zawodowej.

Ostatni temat w opisywanej jednostce tematycznej odnosi się do wiedzy faktograficznej na temat krajów niemieckojęzycznych oraz szczególnych aspektów językowych (dialekty w państwach niemieckojęzycznych, zwroty idiomatyczne). Konstrukcja tego tematu w zakresie wiedzy o krajach DACH polega na naprzemiennym przenikaniu się tekstów informacyjnych na dany temat (kultura, obyczaje) oraz quizów sprawdzających znajomość faktów z zakresu kultury krajów niemieckojęzycznych. W zakresie dialektów jest to kilka ćwiczeń polegających przede wszystkim na tłumaczeniu (wnioskowanie znaczeń z kontekstu), teście wyboru (idiomy) oraz reakcjach językowych, a także bardzo krótkim teście leksykalno-gramatycznym. Trudno zorientować się, według jakiego klucza zostały wybrane treści tych ćwiczeń. Ten ostatni temat ma charakter stricte informacyjny, faktograficzny. Quizy, zgodnie z instrukcją podręcznikową, powinny być rozwiązywane indywidualnie, nie wymaga się tutaj żadnych zachowań interakcyjnych. 


\section{3. Ćwiczenia wdrażające, sprawnościowe i swobodna praktyka językowa}

Przedstawioną wyżej krótką charakterystykę tekstów podręcznikowych można uznać za umiarkowanie optymistyczną, jednakże, jak podkreśla Iluk ${ }^{24}$, jego eksperymenty wykazały, że to nie teksty są nieinteresujące, lecz przede wszystkim metody pracy. Iluk podaje, że $\mathrm{w}$ zależności od formy pracy sam tekst był oceniany jako bardzo nudny lub bardzo interesujący. Analizie poddane zostaną więc teraz ćwiczenia i zadania (łącznie ze swobodną praktyką językową) występujące $\mathrm{w}$ opisywanym podręczniku. Ze względu na objętość artykułu oraz fakt, że wszystkie cztery jednostki tematyczne skonstruowane są $\mathrm{w}$ tej samej konwencji, szczegółowej analizie poddane zostaną ćwiczenia i zadania $\mathrm{z}$ jednostki pierwszej (tj. 4 tematy, czyli przeciętnie materiał na miesiąc nauki) i to tylko te, które rozwijają sprawność mówienia. Dla przejrzystości tekstu przedstawione są $\mathrm{w}$ formie tabelarycznej:

Tabela 2. Wykaz ćwiczeń i zadań z jednostki tematycznej „kultura”

\begin{tabular}{|c|c|}
\hline $\begin{array}{l}\text { Polecenia do ćwiczeń i zadań } \\
\text { z podręcznika (cytaty) }\end{array}$ & $\begin{array}{l}\text { Komentarz do zawartych w podręczniku } \\
\text { ćwiczeń i zadań }\end{array}$ \\
\hline $\begin{array}{l}\text { Porozmawiajcie o tym, co } \\
\text { i gdzie można obejrzeć } \\
\text { w Hamburgu. Wykorzystaj- } \\
\text { cie podane niżej konstrukcje. } \\
\text { Was kann man in....... sehen? } \\
\text { Was kommt heute im Kino/ } \\
\text { Theater? } \\
\text { Was für ein Konzert gibt es } \\
\text { in......? }\end{array}$ & $\begin{array}{l}\text { Dryl substytucyjny osadzony w kontekście sytu- } \\
\text { acyjnym, co nadaje mu charakter komunikacyjny. } \\
\text { Zignorowano tutaj jednak możliwość wykorzy- } \\
\text { stania luki informacyjnej. W rezultacie ucznio- } \\
\text { wie proszeni są o zadanie pytania, na które od- } \\
\text { powiedź znajduje się przed ich oczyma. Takie } \\
\text { aktywności nie powodują ukomunikatywnie- } \\
\text { nia sytuacji lekcyjnej, nie mają też potencjału } \\
\text { motywacyjnego. }\end{array}$ \\
\hline $\begin{array}{l}\text { Kolega proponuje ci zwie- } \\
\text { dzenie wystawy. Dowiedz } \\
\text { się, o jakiej wystawie mowa, } \\
\text { gdzie jest ona zorganizowana, } \\
\text { do kiedy trwa i ile kosztuje } \\
\text { bilet wstępu. }\end{array}$ & $\begin{array}{l}\text { Zadanie umieszczone w procedurze zastosowa- } \\
\text { nia, czyli swobodnej praktyce językowej. Uczeń } \\
\text { proszony jest o zadanie czterech pytań. Nie defi- } \\
\text { niuje się jednak roli odpowiadającego, więc praw- } \\
\text { dopodobnie w ramach tego zadania sformuło- } \\
\text { wane zostaną cztery pytania bez odpowiedzi. }\end{array}$ \\
\hline $\begin{array}{l}\text { Czy warto czytać? Co czyta- } \\
\text { cie? - porozmawiajcie o tym } \\
\text { - jako pomoc podane jest } \\
\text { słownictwo. }\end{array}$ & $\begin{array}{l}\text { Polecenie pozbawione funkcji kierunkującej } \\
\text { i stymulującej, w związku z czym ma charakter } \\
\text { pseudokomunikacyjny. }\end{array}$ \\
\hline
\end{tabular}




\begin{tabular}{|c|c|}
\hline $\begin{array}{l}\text { Polecenia do ćwiczeń i zadań } \\
\text { z podręcznika (cytaty) }\end{array}$ & $\begin{array}{c}\text { Komentarz do zawartych w podręczniku } \\
\text { ćwiczeń i zadań }\end{array}$ \\
\hline $\begin{array}{l}\text { Chcesz zrobić znajomemu } \\
\text { prezent urodzinowy. Wiesz, } \\
\text { że zaczytuje się kryminałami, } \\
\text { ale ty nie bardzo się na nich } \\
\text { znasz. Jesteś w księgarni. Po- } \\
\text { proś o radę księgarza. Zapytaj } \\
\text { o inne książki tego gatunku. }\end{array}$ & $\begin{array}{l}\text { Po raz kolejny w procedurze swobodnej praktyki } \\
\text { językowej należy zadać dwa pytania, rola od- } \\
\text { biorcy jest niejasna. Dodatkowo polecenie jest nie } \\
\text { do konca sprecyzowane, zadanie o charakterze } \\
\text { pseudokomunikacyjnym. }\end{array}$ \\
\hline $\begin{array}{l}\text { Co jest dla ciebie sztuką, } \\
\text { a co nie jest, w którym przy- } \\
\text { padku nie jesteś pewien? } \\
\text { Powiedz o tym. }\end{array}$ & $\begin{array}{l}\text { Dryl substytucyjny, bez kontekstu komunikacyj- } \\
\text { nego. Uczeń formułuje } 5 \text { zdań, teoretycznie bez } \\
\text { celu („powiedz o tym” - komu? W jakim celu?) }\end{array}$ \\
\hline $\begin{array}{l}\text { Asocjogram do tematu "Co } \\
\text { jest dla ciebie sztuką?" }\end{array}$ & $\begin{array}{l}\text { Asocjogram z podpowiedziami - najbardziej ty- } \\
\text { powe skojarzenia są już podane, uczeń ma uzu- } \\
\text { pełnić je o inne, własne. Asocjogram jako typowe } \\
\text { narzędzie rozgrzewki został zastosowany w innej } \\
\text { procedurze lekcji. Zastanawia brak logiki. W ćwi- } \\
\text { czeniu wyżej uczniowie, stosując dryl substytu- } \\
\text { cyjny mówią, co jest dla nich sztuką, a co nie. Po } \\
\text { tym następuje asocjogram do hasła "sztuka”. Ko- } \\
\text { lejność wydaje się być odwrócona. }\end{array}$ \\
\hline $\begin{array}{l}\text { Posłuchaj nagrania jeszcze raz } \\
\text { i odpowiedz na pytania. }\end{array}$ & $\begin{array}{l}\text { Selektywne rozumienie tekstu słuchanego, } \\
\text { uczniowie proszeni są o odpowiadanie na pyta- } \\
\text { nia do tekstu. }\end{array}$ \\
\hline $\begin{array}{l}\text { Kolega proponuje ci wyjście } \\
\text { do muzeum techniki. Odrzuć } \\
\text { jego propozycję, bo w ogóle } \\
\text { nie interesujesz się techniką. } \\
\text { Używając przekonujących ar- } \\
\text { gumentów, zachęć go do od- } \\
\text { wiedzenia muzeum sztuki } \\
\text { nowoczesnej i powiedz, że } \\
\text { nie interesujesz się techniką. }\end{array}$ & $\begin{array}{l}\text { Procedura swobodnej praktyki językowej chrak- } \\
\text { teryzująca się absolutnym brakiem swobodnej } \\
\text { wypowiedzi. Brak jakiegokolwiek odniesienia do } \\
\text { rzeczywistości ucznia, bez potencjału motywują- } \\
\text { cego, polecenie niestymulujące do wypowiedzi, } \\
\text { pseudokomunikacyjne. }\end{array}$ \\
\hline $\begin{array}{l}\text { Czy umiesz grać na jakimś } \\
\text { instrumencie? Na jakim? } \\
\text { Opowiedz. - dryl substy- } \\
\text { tucyjny - } 5 \text { zdań - doty- } \\
\text { czący umiejętności gry na } \\
\text { instrumencie }\end{array}$ & $\begin{array}{l}\text { Dryl substytucyjny - } 5 \text { zdań - dotyczący umie- } \\
\text { jętności gry na instrumencie, bez kontekstu } \\
\text { komunikacyjnego. }\end{array}$ \\
\hline $\begin{array}{l}\text { Opowiedz krótko o każdej } \\
\text { scence. Pomogą ci w tym po- } \\
\text { dane zwroty. }\end{array}$ & $\begin{array}{l}\text { Dryl substytucyjny ( } 3 \text { zdania) - opowiadanie } \\
\text { o scenach z dialogów. }\end{array}$ \\
\hline
\end{tabular}




\begin{tabular}{|l|l|}
\hline $\begin{array}{l}\text { Polecenia do ćwiczeń i zadań } \\
\text { z podręcznika (cytaty) }\end{array}$ & \multicolumn{1}{|c|}{$\begin{array}{c}\text { Komentarz do zawartych w podręczniku } \\
\text { ćwiczeń i zadań }\end{array}$} \\
\hline $\begin{array}{l}\text { Jakiej muzyki słuchacie naj- } \\
\text { chętniej? Gdzie najczęściej } \\
\text { słuchacie muzyki? Może sami } \\
\text { muzykujecie albo śpiewa- } \\
\text { cie? Zadawajcie sobie pytania } \\
\text { i pracujcie w parach. }\end{array}$ & $\begin{array}{l}\text { Zadawanie pytań i praca w parach. Do tego za- } \\
\text { dania podane jest słownictwo. Temat prawdo- } \\
\text { podobnie zainteresuje młodzież. Kontekst sytu- } \\
\text { acyjny słabo nakreślony, ograniczony do narzuce- } \\
\text { nia formy dialogu. }\end{array}$ \\
\hline $\begin{array}{l}\text { Rozmawiasz z kolegą o mu- } \\
\text { zyce. Zapytaj go, jakiej mu- } \\
\text { zyki słucha najchętniej. Wyraź } \\
\text { swoje zdanie na temat jego } \\
\text { ulubionego rodzaju muzy- } \\
\text { ki/wykonawcy/zespołu mu- } \\
\text { zycznego. Opowiedz o swoich } \\
\text { ulubionych wykonawcach. }\end{array}$ & $\begin{array}{l}\text { Zadanie bardzo podobne do poprzedniego, przez } \\
\text { to prawdopodobnie mało motywujące do działa- } \\
\text { nia jęzogo. }\end{array}$ \\
\hline
\end{tabular}

Jak wynika $\mathrm{z}$ przedstawionej $\mathrm{w}$ tabeli analizy jednego rozdziału podręcznika, sprawność mówienie inicjowana jest przez podręcznik 11 razy, 3 razy pojawia się dryl substytucyjny, 4 razy reakcja na opisaną sytuację (każdorazowo $w$ procedurze zastosowania), 2 razy dialog $w$ parach, 1 raz uzupełnianie asocjogramu, 1 raz odpowiadanie na pytania do tekstu. $W$ tym miejscu należałoby podjąć próbę odpowiedzi na pytanie, czy taka propozycja aktywności lekcyjnych daje szansę na ukomunikatywnienie procesu formalnej nauki języka obcego. Przyjrzyjmy się zatem w pierwszej kolejności drylom gramatycznym, które z definicji niewiele mają wspólnego z autentyczną komunikacją. Inaczej jednak na ten problem patrzy Komorowska ${ }^{25}$. Przekonana o konieczności ich zastosowania celem wyćwiczenia pewnych struktur, proponuje takie zainscenizowanie „ćwiczeń gramatycznych, poprowadzenie ich według takiego scenariusza i z taką instrukcją poprzedzającą ćwiczenie, aby nabrało ono pewnych cech autentycznego porozumiewania się, wspólnego załatwienia jakiejś sprawy czy wręcz wspólnej zabawy”26. Komorowska podkreśla dalej, że „z metodycznego punktu widzenia ćwiczenie nie ulega zmianie, jest ono nadal drylem imitacyjnym czy transformacyjnym. $Z$ punktu widzenia ucznia przestaje być wówczas prostym przetwarzaniem tej samej konstrukcji zdaniowej kilkanaście razy, czy też przekształcaniem jej w inną; staje się działaniem wymagającym użycia języka po to, żeby coś zdziałać, wykonać, zrobić, przedsięwziąć,

25 H. Komorowska, op. cit.

26 Ibidem, s. 118. 
a nie tylko po to, by nauczyć się danej konstrukcji, choć to ona właśnie jest naszym etapowym celem lekcyjnym" ${ }^{\prime 27}$. Swoje teoretyczne twierdzenia Komorowska przekuwa $\mathrm{w}$ bardzo liczne praktyczne przykłady komunikacyjnego zastosowania dryli gramatycznych. W analizowanej jednostce lekcyjnej nie mamy jednak do czynienia z komunikacyjnym wymiarem dryli. Nie licząc pierwszego przykładu, gdzie kontekst sytuacyjny został wprawdzie nakreślony (ale zadawanie proponowanych pytań wydawało się nie mieć sensu ze względu na odpowiedzi dostępne dla każdego ucznia), pozostałe dryle pozostają typowymi ćwiczeniami gramatycznymi.

Duże oczekiwania komunikacyjne wiąże się z reguły ze swobodną praktyką językową. To taki czas lekcji, w którym oczekuje się zastosowania wiedzy i umiejętności uczniów, które zdobyli oni w poprzedzających procedurach lekcji. To czas na autentyczne zadania komunikacyjne, bo choć podejście zadaniowe w kontekście polskim nie znalazło zastosowania i nie dysponujemy podręcznikami, które byłyby skonstruowane zgodnie z jego wytycznymi, to fakt ten nie przesądza ostatecznie sprawy. Pewną skuteczność komunikacyjną przypisuje się również nauczaniu wspomaganemu zadaniami, gdzie proces dydaktyczny rozumiany jest bardziej tradycyjnie, a zadania stosowane są głównie jako narzędzia służące rozwijaniu płynności wypowiedzi ${ }^{28}$. Dlatego też oczekiwania komunikacyjne wobec swobodnej praktyki językowej są jak najbardziej uzasadnione. Niestety $\mathrm{w}$ analizowanym podręczniku swobodna praktyka językowa ogranicza się do zadawania pytań na określony temat. W żadnym razie nie można mówić w tym przypadku o ukomunikatywnieniu sytuacji lekcyjnej. Jednak w kontekście mało komunikacyjnych zadań w procedurze swobodnej praktyki językowej warto odnieść się do problematyki formułowania samych poleceń, gdyż to one właśnie wydają się w pewnym przynajmniej stopniu przesądzać o niepowodzeniu zadań swobodnej praktyki językowej w analizowanym podręczniku. Zgodnie $\mathrm{z}$ dzisiejszą wiedzą polecenie powinno być traktowane jako instrukcja, która spełnia dwie funkcje: kierunkującą i stymulującą (...) Polecenie do zadania komunikacyjnego powinno wyraźnie określać cel dialogu i warunki wykonania zadania. Nauczyciel lub autor podręcznika musi dostarczyć uczącemu się punktów odniesienia, które pozwolą mu podjąć działanie zgodne z wytyczonym celem, prowadzące do jego realizacji ${ }^{29}$. Być może, gdyby udało się przeformułować część poleceń podręcznikowych, mogłyby one nabrać komunikacyjnego charakteru.

27 Ibidem.

28 R. Ellis, Language teaching research and language pedagogy, United Kingdom 2012.

29 I. Janowska, Podejście zadaniowe do nauczania i uczenia się języków obcych. Na przykładzie języka polskiego jako obcego, Kraków 2011. 
Pozytywnym akcentem $\mathrm{w}$ analizowanym podręczniku jest na pewno prowadzenie dialogów w parach (dwukrotne w opisywanym przypadku). Równoległa rozmowa kilku osób w sposób oczywisty zbliża formalną naukę języka do autentycznej komunikacji, chociażby dlatego, że generowany w trakcie rozmów hałas stanowi naturalny szum komunikacyjny. Czynniki zagłuszające występują również w nagraniach dialogów. Na przykład wywiadowi przeprowadzanemu na ulicy towarzyszą dochodzące $\mathrm{z}$ oddala odgłosy przejeżdżających samochodów. Sam wywiad jest jednak przeprowadzony w bardzo nienaturalny sposób. Odpowiedzi udzielane "dziennikarzowi” są pełnymi, jak gdyby wyuczonymi odpowiedziami, których w rzeczywistych warunkach nie można raczej usłyszeć w tzw. wywiadzie ulicznym.

W podręczniku występuje relatywnie dużo tekstów do słuchania, mniej jest tekstów do czytania. Z jednej strony można by stwierdzić, że jest to ukłon w kierunku szczególnego kształcenia w zakresie recepcji. Nie można jednak do końca zgodzić się z takim tokiem argumentacji ze względu na rodzaj i jakość występujących tutaj tekstów. Jak wspomniano wcześniej, są one uproszczone, mocno zdydaktyzowane i nieprzypominające w niczym tekstów autentycznych (poza kilkoma nielicznymi wyjątkami). W związku z tym nie mogą być rozumiane jako "dobry input”, który zgodnie z teorią Krashena ${ }^{30}$ powinien być m.in. na odpowiednim poziomie, czyli nie za trudny i nie za łatwy, przekazany w odpowiednich ilościach, czy też wystarczająco zróżnicowany. Tych cech brak na pewno tekstom występującym w opisywanym podręczniku. Dodatkowo rezygnuje się tutaj z wykorzystania poleceń jako źródła danych wejściowych językowych i obok wersji niemieckiej występuje również polska wersja polecenia.

\section{Podsumowanie}

Podsumowując przeprowadzone badanie stwierdzić można, że przeanalizowany podręcznik $\mathrm{w}$ bardzo niewielkim stopniu zapewnia ukomunikatywnienie procesu dydaktycznego. Poza nielicznymi przykładami autentycznych tekstów i ćwiczeń wykorzystujących pojedyncze (też nie zawsze we właściwy sposób) cechy charakterystyczne komunikacji międzyludzkiej, podręcznik zawiera przede wszystkim zdydaktyzowane teksty i ćwiczenia pseudokomunikacyjne. W podręczniku trudno też dopatrzeć się realizacji wytycznych sformułowanych w teoretycznej części artykułu. Nie znajdzie się tutaj zadań proponowanych 
przez Komorowską ${ }^{31}$. Niewiele jest też zadań zaczerpniętych z typologii Ellis ${ }^{32}$. Szkoda, ponieważ propozycje badaczy z powodzeniem można byłoby zastosować dla każdego tematu, również dla tych proponowanych w opisywanym podręczniku, a w sposób szczególny w odniesieniu do osób uczących się języka obcego trzeci rok.

Dobrym narzędziem służącym zmianie optyki lekcyjnej na bardziej komunikacyjną są na pewno polecenia do ćwiczeń i zadań. W opisywanym podręczniku jednak potencjał dobrze sformułowanych poleceń nie został wykorzystany. Ograniczają się one do prostych instrukcji, koniecznych do zrozumienia i wykonania ćwiczenia. Brak w nich informacji chociażby o tym, kto z kim rozmawia (jakie są role uczniów), jacy są uczestnicy, jaka jest sytuacja, jak ona przebiega, gdzie się dzieje, jaki jest problem, o co chodzi, dlaczego itd. Sformułowanie polecenia w oparciu o te wytyczne (pytania) dałoby realną szansę na m.in. realizację zadań, które proponuje Ellis w drugiej części tabeli, czyli rozwiazywanie problemów, projekty i zadania kreatywne czy też dzielenie się osobistymi doświadczeniami. Taki rodzaj zadań mógłby pozytywnie wpłynąć na wzrost motywacji uczących się.

Podręcznik jako podstawowe narzędzie pracy nauczyciela pełni ważną funkcję w skali całego procesu dydaktycznego. Na pewno w wielu przypadkach w sposób zdecydowany determinuje przebieg lekcji, dyktując, jakie ćwiczenia i kiedy będą realizowane. Ale nawet $w$ sytuacjach, kiedy nauczyciel jest bardziej samodzielnie działającym podmiotem, podręcznik stanowi dla niego ważny punkt odniesienia. Jest też prawdopodobnie pierwszym i najważniejszym źródłem pracy, powtórek oraz informacji w zakresie języka docelowego dla uczniów. Na pewno nie jest łatwo sprostać wszystkim wymaganiom stawianym podręcznikowi. Poza tym, że musi on spełniać szereg kryteriów formalnych, technicznych, merytorycznych, dodatkowa trudność wynika z bardzo heterogenicznej grupy odbiorców. Określenie wspólnego przedziału wiekowego i statystycznego poziomu rozwoju poznawczo-emocjonalnego to bardzo ogólna i mglista wskazówka. Niemniej jednak, mimo wszelkich trudności i być może ostatecznej niemożności stworzenia podręcznika idealnego, należałoby podejmować próby stałego doskonalenia koncepcji podręcznikowych, tak by mogły być one wyzwaniem dla ucznia i wsparciem oraz inspiracją dla nauczyciela. $Z$ pewnością jest wiele dróg dojścia do tego celu. Skoncentrowanie uwagi na komunikacyjnym potencjale zadań podręcznikowych może być uznane ze jedną $\mathrm{z}$ nich.

\footnotetext{
31 H. Komorowska, op. cit.

32 R. Ellis, op. cit.
} 


\section{Bibliografia}

Allwright R.L., What do we want teaching materials for?, „ELT Journal 36" 1981, 1, s. $5-18$.

Ellis R., Language teaching research and language pedagogy, United Kingdom 2012.

Iluk J., Jak (de)motywujemy uczniów na lekcjach języka obcego, "Języki Obce w Szkole” 2013, 4, s. 67-74.

Janowska I., Podejście zadaniowe do nauczania i uczenia się języków obcych. Na przykładzie języka polskiego jako obcego, Kraków 2011.

Komorowska H., Ćwiczenia komunikacyjne w nauce języka obcego, Warszawa 1988.

Kusiak-Pisowacka M., Ewaluacja podręcznika w nauczaniu języków obcych, „Lingwistyka Stosowana" 2015, 14: 3, s. 65-75.

Krashen S.D., The Input Hypothesis: Issues and Implications, New York 1985.

Lewicka G., Glottodydaktyczne aspekty akwizycji języka drugiego a konstruktywistyczna teoria uczenia się, Wrocław 2007.

Lewicki R., Poznaj język sasiada. Program nauczania. Język niemiecki, Warszawa 2002.

Pfeiffer W., Nauka języków obcych. Od praktyki do praktyki, Poznań 2001.

Potapowicz A., Tkaczyk K., Aha Neu! Język niemiecki. Podręcznik z ćwiczeniami dla gimnazjum. Kurs podstawowy 3B, Warszawa 2011.

Swan M.A., The textbook: bridge or wall?, „Applied Linguistics and Language Teaching" 1992, 2/1, s. 32-35.

Swan M.A., A critical look at the Communicative Approach, http://seas3.elte.hu/co-urse material/HalapiMagdolna/Swan1.pdf, [online], dostęp 15.08.2017.

Willis D., Accuracy, fluency and autonomous learning: A three way distinction, 2007, http://www.willis-elt.co.uk/books.html, [online], dostęp 15.08.2017.

\section{Źródła internetowe}

Kompetencje kluczowe w procesie uczenia się przez całe życie, http://eur-lex.europa .eu/legal-content/PL/TXT/?uri=LEGISSUM\%3Ac11090, [online], dostęp 15.08.2017.

Raport o stanie edukacji 2013. Liczą się nauczyciele, http://eduentuzjasci.pl/publika cje-ee-lista/raporty /150-raport-o-stanie-edukacji/1052-raport-o-stanie-edu kacji-2013-licza-sie-nauczyciele.html, [online], dostęp 1.07.2017. 